\title{
Book Review of Irreligion
}

\section{Book Review of}

Irreligion: a mathematician explains why the arguments for God just don't add up, by John Allen Paulos (2008) Hill and Wang, New York, USA, pp. 158.

This book is an intellectual placebo. The author is a prolific mathematician who does not believe in God or religion and cannot compute beyond himself:

My own feeling derives in part from the realization, mentioned in the preface, that I had when I was ten years old and wrestling with my brother on the floor of my family's house in Milwaukee, Wisconsin. In an important sense, I mused, there was no essential difference between me and not-me; everything was composed of atoms and molecules, and though their patterns differed, the rug below our heads and the brains inside them were made of the same stuff (Pg. 81).

No doubt doubt happens when your face is being ground into the rug and you likely thought you were going to die. "How many seconds do I have left?" and you merged with the rest of the world by counting defensively, fleeing to and obsessing about axioms, integers, polynomials and sets forever. Inflated with years of computational study and rug burned, he decides to wrestle with God and apply, superficially at that, his math to all programmed parodies of the theories and assertions for belief in God. As a result, he provides an ecumenical calculus of nil correspondence i.e., there is nothing there. It is worse than that, because the if then, good*bad formula of physicist Steven Weinberg is offered as a redemption of gadfly sorites (and proof of ordure particles in elementary and sterquilinous physics!):

With or without religion, good people will do good, and evil people will do evil, but for good people to do evil, that takes religion (Pg. 139).

In spite of that statement and in self-contradiction, Paulos, without taking religion, does evil himself as he fails to apply universally and equally his mathematical doubt-proof analyses to himself, Weinberg and other atheists' "unrelated irrelevant infallible banalities," a phrase he shortsightedly again applies only to theories asserting the existence of God (but I apply that phrase, clearly justified, to Paulos himself, other unbelievers and their unscience too!). Truly, if he does not apply his aflatus numerology to himself and like boneheads, what good is it except a strawman argument against those not tolerated? Paulos most assuredly does not program his mathematical compatability invariants to Charles Darwin or to the theory of evolution in which he, no doubt algebraically oddball, believes. An ocular problem is evident in that he cannot see that the numbers for evolution are the ones that "just don't add up" (a phrase I subtracted from his book titlewhich is about the only part of the book worthy of repetition) and which I demonstrated in "The Celebration of Charles Darwin (or is it time for an inquest?)", soon to be published by Social Justice Review.

Volume 2 Issue 5 - 2015
Dr. Samuel A Nigro M.D*
Retired, Assistant Clinical Professor Psychiatry, Case Western
Reserve University School of Medicine, USA
*Corresponding author: Dr. Samuel A Nigro M.D, Retired,
Assistant Clinical Professor Psychiatry, Case Western Reserve
University School of Medicine, 2517 Guilford Road, Cleveland
Heights, Ohio 44118, USA, Tel: 216 932-0575; Email:
sam@docnigro.com
Received: August 19, 2015 | Published: October 7, 2015

Paulos admits that he should not be "dismissive of this (God seeking) yearning for transcendence" (Pg. 76), but he then does not follow his own advice and divides himself with repetitive mathematical ethnic cleansings often duplicating Darwin in the repeated multiplication of imaginary examples among other resentments of the joyful compounding of belief by believers. The "nothing there" formulae have never been more "nothing there" or nil. I prefer: duh+duh+duh+duh = Beethoven's Fifth...the victory notes are not for losers or the negative number people or pi square-rooted atheists. Of course, Paulos does not understand human particles begin from a conception singularity and expand transcendentally ( $\mathrm{T}$ ) in activity on the right conservative side of the equation balanced on the liberal looney left by the dumbo (lambda was already taken) constant of atheism X the distance from God squared X the coefficient of sin taken to the power of one's age in years; this was proven by the well known conversion loveshift, the elimination of quacks (not quarks) and Godel's proof of the phenomenon of suggestibility (also known as Original Sin); and the final human death singularity has the human particle condensing (if Ts, Ss, and Vs are large enough) into the Statimuum as originally defined in my book, Happy Ending. This of course is the Theory of General Sacramentality and Specific Sacramentality (See footnote), but I digress.

Overall, this book, irreligion, is silly and superficial and Paulos sums himself up nicely on page 79 :

It's repellent for atheists or agnostics to personally and aggressively question others' faith or pejoratively label it as benighted flapdoodle or something worse. Those who do are rightfully seen as arrogant and overbearing.

That apophasis, dear reader, is a different kind of duh (actually a huh?) and is an unwitting self-algorithm of author John Allen Paulos in person who does not understand himself yet. Here it is in the math I learned: $(1-1=0)$ which should be the price tag for this book. No, I correct myself: He should pay you to read it, because you feel like you have lost your identity because someone is grinding your head into a rug. This book is too thick to be true. You are better informed by reading The Devil's Delusion: Atheism and its Scientific Pretensions by David Berlinski. 
(Footnote: The Theory of General and Specific Sacramantality is:

$\mathrm{Sa}+\mathrm{St}=\mathrm{ia}^{\mathrm{T}}+\mathrm{ia}^{\mathrm{S}}+\mathrm{ia}^{\mathrm{V}} /\left(\mathrm{Dx}(\mathrm{dd})^{2}\right)+(\sin )^{\mathrm{a} y} \quad$ where Sa is Salvation; St is Statimuum; ia is ideas-actions; T is Transcendentals; $\mathrm{S}$ is Sacraments; V is Virtue; D is dumbo, the atheism constant; $\mathrm{dd}$ is the damnation distance from God; $\sin$ is $\sin$; and aiy is the person's age in years. The Theory of Specific Sacramentality is found in the Baltimore Catechism, The Catholic Encyclopedia, or The Encyclopedia of Catholic Social Thought, Social Science and Social Policy.) 